\title{
TURKEY'S FOREIGN POLICY WITHIN THE CONTEXT OF CONFLICTS BETWEEN EUROPEAN AND AMERICAN SECURITY
}

\author{
Hüsamettin INAÇ ${ }^{\circ}$ \\ Ümit GÜNER*•
}

\begin{abstract}
:
$21^{\text {st }}$ century has taken its place in the historical books as a century in which the most tempestuous developments were experienced regarding the World history. This century in which many important events took place such as the two major world wars, disappearing of tens of states from the scene of the history, great economical crisis, collapse of the communism in the Soviets experience, creation of a new life form after the technology has been placed in the centre of the life, political crisis and atom bomb, has also the nature of being one of the most bloody centuries about which the world history had witnessed. When we look at the aforementioned events, we see that the crisis and wars formed the milestones of this century. What is ironic is that the Human Rights Declaration was also proclaimed and ratified in this century. Wars are the time periods in which the intercultural interactions are most intensive and destructive. The definitions of "Cold War" and "hot war" made related with the intensities or profiles of the wars display that basically any time period without any war, conflict or struggle is not possible.
\end{abstract}

Keywords: ESDI, NATO, WEU, Eurocorps, Goe-strategy/politics.

$\ddot{O}_{z e t}$ :

21. yïzyıl dünya tarihi açısından en firtınalı gelişmelerin yaşandığı bir yüzyll olarak tarih kitaplarında yerini almıştır. İki büyük dünya savaşı, onlarca devletin tarih sahnesinden yok oluşu, büyük ekonomik krizler, komünizmin Sovyet deneyiminde çökmesi, teknolojinin hayatın merkezine yerleşerek yeni bir yaşam biçimini ortaya çıkartmast, siyasi krizler, atom bombası gibi önemli olayların yaşandığı bu yüzyll ayrıca dünya tarihinin

\footnotetext{
- Assist. Prof. Dr., Dumlupinar University, Public Administration Department

•. Dr., Dumlupinar University, Economics Department
} 
gördüğ̈̈ en kanlı yüzyıllardan birisi olma özelliğini de taşımaktadır. Yukarıda sayllan olaylara baktığımızda görmekteyiz ki; yüzyllın dönüm noktalarını krizler ve savaşlar oluşturmuştur. Ironik olan ise Insan Hakları Deklarasyonunun da bu yüzyllda ilan ve kabul edilmiş olmasıdır.

Anahtar Kelimeler: AGSK, NATO, BAB, Avrupa Ordusu (Eurocorps), Jeo-strateji/politika

\section{Introduction: Transforming Aspects of the Theoretical Framework}

The conceptualisation of the Cold War used for defining the conflict between the United States of America and the Soviet Union, lost its meaning by the blowing over of the Soviet Union from the scene of the history and America proclaimed its sovereignty as the single power in the univocal world. This situation does not have the meaning that United States of America is unopposed or dominates across the world alone. The market conditions of the capitalism which increase the competition enabled the presentation of the new powers in the world scene and with the expression of "Brzezinski" the game on the "chess board" has been acquired a new shape (Brzezinski, 1997). On the contrary of the thesis1 that accept America and Europe as the carrying characters of the same culture, serious conflicts and resolutions had been experienced between the members of the European Union and America. On the other hand, the effective power of America in the international organizations such as United Nations and NATO caused appearance of new formations. Even if they are minor initiatives per character, it is not possible to tell that the decision of the Asian States to act together, forming of the commercial consortiums of China and Russia, the decision of the Islamic States to act together in the field of industry and trade, the common region initiatives of the states with the shore to the Black Sea will not have an effective importance in the future of the world. Moreover, European Union has risen in the position of a global actor as the long-term result of a commercial agreement.

When we examine the establishment aims of the European Union, it is possible to see the progress, which is realized, in the form of solution seeking for the general problems of $20^{\text {th }}$ century. Besides its political structure, the commercial aspect of the Union which is an important formation regarding the establishment of a sustainable peace in the 
continent of Europe which experienced the most bloody two world wars in history, constitutes an important capacity. It is targeted that the member states would form a common market and they would reach higher life standards together with this common market. On the other hand, in order to provide the full employment, the moves made in order to realize the "Economical Integration" created successful results. The development phases of the Union overcame serious crisis but even if it could not provide a political unity for today it has become an effective and important power in the unipolar world. Besides the data verifying the claim of that it is a cultural union, it is also possible to say that the union is a structure which targets to maximize the sole economical interests. In addition to all of these, it is also a reality that in direction of the discussions of the European Union Constitution, the religious aspect of the Union can be accepted under the cultural umbrella. When these identification attempts are handled one by one, they will not go beyond being definitions which are incomplete and misleading, because, European Union is also an economical union, a cultural union, a commercial union and at the same time, it is a structure which embraces all of these characteristics (Çalış, 2001).

Determining of Turkey its location within this structure requires a hard decision taking process. Besides Turkey's, which has strategic cooperation with the United States of America, displaying a performance parallel to the American politics in the regional scale and forming an American ally profile in many areas, application for the full membership to the European Union and undesigning important reforms at the membership point, puts forward an interesting dilemma regarding the strategy and diplomacy (İnaç, 2005). At this point, besides Turkey's own preference, the decisions to be given by the European Union and America are also important. Although as being an important representative of the Islamic World regarding it's historical and cultural inheritance, if Turkey will adopt a regional collaborator's role or a global actor role in the new cyclical situation is facing us as a question whose answer is uncertain, it will not be very wrong to say that Turkey has the potential of being a global actor. For the time being Turkey is at a very serious parting of the ways. The American academicians such as Samuel Huntington and Graham Fuller put forward the thesis of that Turkey which gave up adopting western practices and Islamised again will become the leader of the Islamic World, which can establish more friendly relations 
with the Western part. But this scenario based on economical and political isolation will cost high regarding Turkey and may be it will result with a disaster. Positioning of Turkey as an Islamic Model Country may always sustain its existence as an alternative, but this approach will cause also the minimization of the political performance of a marginalized country in the international arena. The expectation of being a model for the other countries of a country, which is attenuated and lost its respectability in the international arena is very unrealistic. On the other hand, to set to work to be the leader of the Islamic countries will not be very hard for a Turkey which defines it's Islamic identity and uses the tools of the diplomacy correctly. There is no other country among the Islamic countries and in the Middle East geography, which deserves the "democratic" definition much more (Fuller, 1996). In order to be able to suppress terrorism, the way for the destruction of the terrorist organizations, which are fed by the radical religious elements, passes through providing the sovereignty of democracy all over the World.

There are key points in the willing attitude of Turkey for the membership to the European Union. Full membership perspective brings with itself the requirement of the creation of a deeper, different and detailed dialogue atmosphere than the current one, between Turkey and Europe, both at the official and private sector level and at the level of non governmental organizations and even at the level of individuals. Even though the discussion process includes difficult phases, the effort and good will, which the parties will show, will determine the faith of the discussions. It is required to overcome the mutual hesitations, doubts and mistrusts and whatever their reasons were until now, the relations be taken out from a kind of hostile atmosphere and introduced in a cooperation and support atmosphere. Shortly, the establishment of strong partnership relation is required.

On the other hand, it is a handicap that the important problems, which may harm the image of Turkey, still stand in the first rank of the country's agenda (Özcan, 2000). A pessimist picture appears when the problems of the violations of the human rights, which are delicately followed by the international public opinion, are added in the problems such as terror, inequality between the regions, effect of the crisis economy on the market and instability. On the other hand, it is difficult to able to overcome the historical accumulation under the oriental imagination's perception of 
Turkey. Perception of Turkey with an image of men with fez, prayer beads and baggy trousers are the negative effects regarding the image of Turkey. Many people in the West Europe having limited knowledge about Turkey and being mislead by what they heard from their own media, unavoidably shows more terrifying the uncertainties which will be brought by accepting among themselves a large Islamic Mediterranean nation which is agitated by a serial regional disagreements (Çomak, 2005).

Although it is wrong to say that the elements, which take place in this pessimist picture, will continuously exist as the insurmountable problems, solution of these problems requires a serious time period and determination (Inaç, 2005). Another matter not to be forgotten about the dimension of the relations is the profit and loss statement. It is wrong to believe that Turkey will carry chronic problems to European Union and these problems are unsolvable. There are many contributions Turkey may bring with itself into $\mathrm{EU}$, such as a great and powerful economy, a pivotal regional and strategic role, a position of arbitrator in the relation with Asia and a powerful actor, which may contribute to the dialogue process with the Islamic countries. The positive contributions, which we specified above might enable that European Union, may go further than being a single dimensional cultural formation and ranks a more effective position in the global scale.

Many deep concerns of Turkey will be solved with the EU membership. For example external security state will be very different as soon as Turkey participates in the European Union and will not face any questions about it's full status within the structure of European Security Defense Policy (ESDP) In fact while Turkey could be included in the policies formed in this area, as the membership discussions will be realized in a very long time zone, it will hinder the support or contribution of Turkey regarding ESDP. In the future years, it seems that EU will become a more effective actor in the international scene with an active foreign policy and its security interests outside of the NATO region. Turkey may play an important role in the protection of peace and security strategy of the Union in the future (Erdoğdu, 2004). The military power and experience Turkey has, carries it to a different location.

Today, the dimensions of security concept are being expanded and reshaped. The scope of the military activities directed to the provision of the 
country security and defense of the country territories is expanded and in addition to the current military aspect, the political, economical, social and technological aspects gained importance. Now the security concept targets are not intervention but prevention (Ülger 2002) The future security environment will be dependent on the realization of the countries to struggle with international terrorism, democratisation and economical developments. The sustainability of the peace in the world will be secured in a ratio of the realization of these by the states. Now, the terror is beyond being a local action but gained an international dimension. It is not sufficient for the countries to constitute a security area within their own territories in order to secure their stabilization. In the pro-WEU scenarios it is evaluated that the threat directly directed to Europe will be the threat created by the nuclear, biological and chemical weapons and the threat, which will be created by the international terrorism. So, the concepts of war and peace gained a very different meaning in the $21^{\text {st }}$ century. It is very important for the future of the world that the international security policies be functionalised and gains a preventive nature beyond being a power of intervention. Today, the European Security Policy left the understanding of "defence based on the protection of the boundaries" and directed to the "strategic security" concept based on the principle of "protection of the interests beyond the boundaries and solution on site without enabling the negative developments" (Dinkelaker, 1997: 2).

When we examine the sources of the terror cases occurred in Europe, besides the European-sourced terror organizations such as ETA in Spain, we also see the international terrorist organizations such as Al-Qaeda. When the wars experienced by the European geography after the disintegration of Yugoslavia are taken into consideration, it is seen that although European Union succeeded in being a commercial, political and cultural union, it could not succeed being a "secure" union as territorial. In this context, ESDP will remove a serious deficiency.

Regarding the security of Europe, the most important development after the Cold War is trend of Europe towards the "crisis management operation" instead of "collective defence" as result of the removal of the threat and starting to form its power structure according to this. The capacity of European Army, which is formed in this context, is rather limited when 
compared to NATO. The duty for the protection of the peace does not combine with the meaning of security in the $21^{\text {st }}$ century. Because the intervention made to the region after the war is not an intervention, which could hinder human losses, remove the economical crisis and revive the historical and cultural heritage, which is diminished. ESDP includes an Emergency Intervention Power in order to provide the military intervention of the EU countries in the "international conflicts and problems". EU member countries have taken a decision to form a military power parallel to the function of NATO in the international area. This decision taken under the name of European Security and Defence Policy is predicated on "benefiting all the opportunities and capabilities" of NATO, while providing the establishment of European Army which will consist of EU member states for the purpose of the protection (defence) of the markets of the EU member states and intervention to the international conflicts (security). In this way, the European Army will be established on the basis of automatically using all the command control systems, transportation, communication and information possibilities of NATO member states, which means directly in the situations when they decide the intervention and without informing the related country. In the conditions when the mentioned possibilities belong to the EU member countries, there will not be any problems because these countries will directly take place in the decision taking mechanism. But although Turkey is a NATO member, it is not yet a member of EU. At this point, it becomes obvious that Turkey is a very important country regarding the membership discussions. When we examine the reasons behind the discussions related with Cyprus, we see the security problem and authorization area of ESDP. Today, there are 3 components for the stationing of a military power as the "emergency intervention power" (Norton, 2000):

- Aircraft carriers,

- Long ranged bomb planes,

- Strategic military bases.

Although the first two of these components, which means aircraft carriers and long ranged bomb planes, are producible directly by the military industry, the strategic military bases are directly related with the geopolitical positions of the countries. When the geopolitical location of Turkey is taken into consideration it will be obvious that Turkey may serve 
as a boundary and its importance regarding its preventive security will be understood. This geopolitical location becomes the places which concerns Turkey and Cyprus in the first degree from the view of European Army. With other words, the geopolitical location of Turkey and Cyprus is in the state of determinant for all the operational efficiency of European Army.

As known, the island of Cyprus, which takes place at the far east of Mediterranean, is in the nature of a suitable natural aircraft vessel in order to be able to intervene to the problems. A military base to be established in Cyprus will make possible of the intervention to the whole region from the Balkans, to the Middle East and Caucasus and at the same time it will be able to be used as a political-military threat element. Besides the effect of England on the Island as being the guarantor state, the special interest, which America shows for the Island, causes the display of a political and military struggle in Cyprus. It is obvious that by the suspending of the discussions on the Annan Plan by the Greek section and blockage of the discussions, the Cyprus problem will increase the diplomacy traffic between European Union, United States of America, Turkey and Greece (Mat 2003). The power and capability of Turkey in the military area has been clearly put forward with the duties it served within the NATO. Turkish soldiers within the peace power in Bosnia Herzegovina and Afghanistan played an effective role for the gaining of stability in the region and contributed for the people to be in peace.

NATO which was established in the Cold War period as a military alliance had lost its potential enemies during the establishment period and requires an "another producer" in order to be able to define its identity and needs to have a new target in order to be able to sustain its existence. This discussion extending since from the straggle of Union of Soviet Socialist Republics requires the examination of the existence of NATO and opens it for the discussions with itself. Because NATO has been impersonated as a late intervention power as in the example of Yugoslavia or an approval authority as it was during the occupation of Iraq by America. Since United States of America, under the topic of "war with the terror" set to work in order to change the world map which was drawn in the period starting from the beginning of $20^{\text {th }}$ century until the end of the $2^{\text {nd }}$ World War, it tries to cut a new dress for NATO which it holds the political control of. In the NATO meeting made in Warsaw, the Ministry of Defence of USA in that 
period, Rumsfeld clearly defined the new duty, which America appraised for NATO as "NATO should left being a power directed to defence and it should be converted to an attack power which can interfere the crisis regions". (Mat, 2003). With such a definition the dimension to be gained by the functionality of NATO is doubtless a matter of concern. With other words, it is possible that NATO which America will want to use as an extra military power whenever it wishes, will loose its characteristics of being reliable and objective.

\section{Security Concept in EU}

Aim of the international economical integration is to increase the welfare levels of all states under their structure. European Union (EU) has accepted to increase welfares of member states as a whole as basic target since its establishment and established Common Agricultural Policy and Common Competition Policy like common policies at first stage in connection with this aim and implemented these policies successfully (Ülger, 2003).

With considering that a full welfare increase in the Union is hard to maintain, since 1975, a Regional Development Policy, aiming to reduce the economical and social development differences between member states and regions of these states, has been established (İçli, 2003). In the entry section of the 1957 dated Rome Act, which is the basic Act establishing the European Society (ES), it is referred that development differences among regions should be removed for successful economical integrity of the member states. But, no common policy has been established on this issue till 1975 (Ar1, 2002).

\section{Historical Aspect of Security Concept in European Union}

Reflections of new power balance, formed by global based events occurred after World War Two and different security understanding brought together with it in the territorial Europe, are reaching to the end of 1940s (İcli, 2003). Insufficiencies in common security and foreign policy in the Europe in real meaning, has reached to different dimensions with the unique atmosphere of the period after 1991. Europe, which experienced wars triggered by historical disputes and internal dynamics, was a scene for the desire to locate United Europe ideal to the reel-politic axis from Napoleon to Hitler. While intellectual basis of this ideal reaches to Medieval, 
advantage of having same cultural heritage shall be benefited after experiencing European-centred two big wars (İnaç, 2005). In this context, establishment aim, suggesting economical partnership of European Coal and Steel Society, deemed as the base of the European Union, is an indicator for cooperation in Europe on different areas. It is seen that advancements in various areas, from common legal understanding till to the construction of common security architecture, are obtained afterwards.

When establishment of European security concept is considered within historical period, it is seen that West European Union (WEU) has an important share. Together with the establishment of NATO on 1949, inclusion of states within the Western Block has created disturbances for Western European States, especially France, and studies had been performed for establishment of a unique security and defence system for Europe.

\subsection{ESDI}

Regional organizations (NATO, ESDP, EU), to which Western European states are members, has tried to take some measures against the indefiniteness, existed with the ending of Cold War. ESDP is an expansion of common foreign security policy of European Union. ESDI, an independent actor, is a policy, tried to be developed for the purpose of self supplying of security and self defence of EU, which is willing to join to the international system and different from ESDI (European Security and Defence Identity), which is developed under NATO structure.

In the beginning of 1990s, a period, enabling NATO's European side composing states to take more responsibility on their common security and defences, has been started. It is desired to establish a real European military skill without repeating the possibilities and skills within NATO (Davutoğlu, 2001). Also with this approach both a balanced partnership shall be established between two sides of Atlantic and during integration of Europe, common foreign security policy realization desire shall be covered. Development of a European security and defense identity within NATO composes a part of the applications within political and military structures of NATO. This is also composing an important element of development of European Union. During development period of USA, it is based on 1991 Maastricht, 1997 Amsterdam agreements and explanations of WEU related 
with these and NATO's 1990 London, 1994 Brussels, 1997 Madrid and 1999 Washington summit resolutions.

European Security and Defense Identity is being used as a concept, increasing the self defense responsibilities of European nations (Norton, 2000). European Security and Defense Identity and European Security and Defense Policy, which are commonly confused with each other and used instead of each other, are indeed two different contented organizations. While ESDI is holding more conceptual meaning, application is also possible in ESDP. While NATO is trying to develop ESDI within it, EU is trying to establish a separate ESDP.

While European states, after 1990, are willing defense and security works to be left to them, EU has tried to vitalize WEU first and let WEU to gain skills for performance of military operations. They have declared WEU as defense component of EU and existed a new organization under ESDI name within NATO at the same time (Öztürk, 2001). (ESDI concept is formed as a result of resolutions, made in London and Rome in the beginning of 1990s. This concept is considered under transatlantic connection and for the purpose of strengthening the NATO's European side it is defined as a supplementary activity of ODGP. Development of ESDI within NATO, has an aim of increasing the skills of European Allies in the operations, where US permits them to use the NATO possibilities. Basic factors, underlying establishment of ESDI, can be listed as follows (Meiers, 1999):

- Compliance need of the union to the new world order,

- Gaining defense and security dimension to the union with its economical and political weight

- Balancing the USA weight within NATO and gaining independent movement skill as a union

- Deficiencies, existed in Bosnia and Kosovo

- To have a word on energy resources

- Sharing desire of US of economical burden, borne by US during security of Europe, with European states. 
ESDI, which is firstly mentioned under 1984 Rome Declaration, is officially adopted with 1991 WEU Maastricht declaration. ESDI is started unofficially during January, 1994 Brussels North Atlantic Council meeting. ESDI, which is not only a technical military arrangement, has also a political dimension. In other words, this organization means that NATO and USA are accepting a bigger security role for EU (Mat, 2003: 93 - 94). ESDI - NATO relations has an important position during formation of European security. As an organization, NATO has assisted to the formation of ESDI. In this context, United Common Duty Power, which is activated with Brussels summit, is enabling to use NATO presence and skills without direct interference of US during the operations, to be performed under WEU with the leadership of Europe. As can be understood from here, development of ESDI, which does not include NATO, is impossible (Erdem, 1999 : 2002 - 203).

Under the concept of United Common Duty Power lay idea of "separable but not separated possibilities", which shall bring the European to a level to perform independent military operations with benefiting from currently present possibilities and skills within the alliance instead of creating possibilities again (Meiers, 1999 : 238). ESDI is in parallel with desire of transition to a common foreign and security policy within EU. This concept, which has intend to rebalance the alliance, is the security for Europeans to be more effective during establishing and applying policies. ESDI's role is to perform missions as a combination of nation states within the various security systems of European continent. When observed on can see that there are lots of security and defense identities within NATO. For example, there are one American, one German and one French security and defense identity within the alliance. Importance of ESDI is that it has collected lots of defense and security identity within it.

If we look at ESDI in connection with Turkey, it can be firstly mentioned that main problem of Turkey has started with ESDP and Turkey has supported ESDI. Because, if it is considered that ESDI is indeed a connection between WEU and NATO Turkey, who is a member of WEU, had gained lots of rights. But in the ESDP; which replaced with ESDI, there rights are removed (Çayhan, 1996). As a result, if we should make a general evaluation, EU states, who activate the ESDI, are requested to be evaluated as good intended structure, to be used for interfering to the regional events and only established for reducing the burden instead of 
thinking as an alternative to NATO today. But everybody knows that goodwill can not be mentioned in the international relations, there are only interests of states as well as friendships and hostilities, formed accordingly (Varol, 2001).

\subsection{Eurocorps}

Until today, 3 more countries (Belgium, Spain, Luxemburg) has taken part in Eurocorps, founded on 21-22 May 1992 in French-Germany Summit. It is decided that Eurocorps, which has started to take action after Pegasus 95 practice on November 30,1995, will consist of 50.000 people. Eurocorps is a part of FAWEU (Forces Answerable to the Western European Union). Eurocorps, which can act as part of FAWEU or NATO, can have humane missions decided by UN or OSCE. The agreement of Eurocorps' being under the political control of FAWEU is defined by an agreement on September 24, 1993 and being under the authority of NATO is on January 21, 1993.

Eurocorps, which has power of 3000 people, is situated in Strasbourg. On September 3, 2002, it is approved that Turkey, Greece and Poland will assign personnel to the Eurocorps Multinational Headquarters in Strasbourg. It is expected that Italy will assign one liaison officer to the office to where England and Holland has sent liaison officers before and that the total number of participants will be 13 together with the participation of Austria and Finland.

\subsection{ESDI}

European Security and Defend Identity is the name given to the new defence concept of NATO after the dissolution of USSR. ESDP is the politics developed by European Union as a substitute of West European Union. However, these are confused most of the time and are used with the same meaning with ESDP, which includes the foundation of European Military Force by EU.

ESDP has the mission of founding an Urgent Intervention Force to provide military intervention for EU countries in times of "international conflict and problems". This decision enables the foundation of European Military Force by European Union countries with the aim of defending the markets of EU countries and intervenes in international conflicts. In 
addition to this, it has predicated on "automatic making use of all the possibilities and abilities" of NATO (Gürkaynak, 2004). By this way, European Military Force will be founded on the predicament of using the command control system, transportation, contact, information facilities of NATO countries automatically, that is in times when an intervention is considered to be a need and without the need of informing this to the related country.

European Security and Defence Politics, is the compound part of EU Common Foreign and Security Politics. It can only be considered within the boundaries of it. It activates the military opportunities and abilities that will support EU's foreign and security politics application. This means, the basic political and strategic decisions about ESDP are taken on the upper level, that is General Works and Foreign Affairs Council composed of EU Council or EU Foreign Affairs ministers. (Karaosmanoğlu, 2005).

There are 3 collateral organs directly related to ESDP: Political and Security Committee composed of ambassadors of the member countries; Military committee composed of chiefs of general staff of member countries, and chief of general staff of EU. The responsibilities and duties of these 3 organs are fully consultative and applicable. They have no authority of taking political and strategic decisions and are open to the intervention of EU Council and Foreign Affairs Council. ESDI, is a part of NATO and when considered historically, it is used identically with the taking of more initiative of European countries (Gürkaynak, 2004). It is not used in the sense that EU countries tried to have their security by means of countries other than NATO members.

ESDP, is the part of EU's Associate Foreign Affairs and Defend Politics. This politics giving a direction to the European foreign affairs is a new one when considered relative to the EU politics (Moussis, 2004). Some EU countries opposed to the idea of founding a defence politics in EU. But throughout the time, the member countries settled up the idea of having a military facility rather than having an associate defence (Özdal, 2005).

With the experience we had in the Balkans related to ethnical conflicts, EU decided to form a military force to deal with the events near to its territories and on the condition that USA does not take the initiative. In this sense, the main aim is defined as forming an Urgent Military Intervention Force in the Helsinki Summit on December 1999. The Urgent Military 
Intervention Force will accomplish the Petersburg duties defined in 1992 by WEU (Gnesotto, 2005). In the Helsinki Summit, two reports are accepted about strengthening the European politics and non-military crises in EU. After the acceptance of this report, 3 constant organs are established within EU Council: Political and Security Committee, European Military Committee, and European Military Personnel. These three organs started to act in March 2000.

The first act conducted within the frame of ESDP is the start of EU Police Mission in Bosnia Herzegovina. This mission had undertaken the duty of UN, with the participation of 18 countries other than $15 \mathrm{EU}$ member countries. In March 18, 2003, the military union decided to make its first military operation and undertook the responsibility of UN of securing the peace in Macedonia. (IKV)

EU envisages the establishment of common defence politics step by step and a common security politics covering all the issues related to the security of the union. This means that ESDP constitutes a part of Common Foreign Security Politics (CFSP). This common defence politics may have become a common defence if the 15 memmber countries and European Union Council admitted it. ESDP does not affect the private quality of security and defence politics of some member countries and is in line with the politics of NATO (Özey, 1997). The EU summit in Köln on June 1999, has put the crisis management to the centre of strengthening period of the Common Security and Defence Politics. These are also known as Petersburg duties. This name comes from the name of the place WEU Balkans Council meeting on June 1992.

These duties include, humane helps and rescue, securing the peace, making peace and establishing battle forces in crisis management. With this aim, EU Council decided that "The union should have autonomous acting capacity supported with convincing military forces, have the possibilities of having an agreement of using these forces, and have the required preparation to use these forces without harming NATO's acts." (Altuğ, 1999). All the EU summits (Helsinki, Feira and Nice), gave a more concrete content to the aim of providing an autonomous acting capacity in international crisis management by acknowledging the UN Security Council's authority and in line with the UN Constitutional Law. 
Thus, EU Helsinki summit on December 1999, has decided on the main target regarding military abilities. This means training 60.000 people who will be able to accomplish all Petersburg duties in 60 days until 2003 and hold them at least 1 year. The accomplishment of this aim does not include the foundation of an European army. The sending of national forces and their effect lodgement will be depended on autonomous decisions taken by member countries (Haine, 2006). Most of the summits decided to form new and permanent political and military structures that are a Political and Security Committee and a Military Committee that will provide political and strategic direction in times of crisis. Other than these, the military cadre composed of military experts sent by member countries of the Military Committee is included within the structure of Council Secretary. When needed, some meetings are done between the union and NATO about some specific issues on the union's being able to start military interventions by using NATO's abilities and assets.

Most of the latest interventions of EU within the frame of ESDP is focused on the period after the stability is established, including civil subscriptions and gendarmerie interventions. But when we look at the missions of European peace defence officials, these missions are seemed to be the results of military interventions. If there were no NATO intervention, there would not be a peace to defend in the Balkans. The discussions of ESDP and NATO are in one sense related to decreasing the power of national military forces and making these two military agreements the most powerful military force in global terms.

New studies have started within the fields of information and the prevention of terrorism act. EU has determined a very clear operation and force frame to prevent the use of nuclear guns and has started an unprecedented collaboration for the intervention to Iran. The most important thing is that a EU Security Strategy is legally admitted on December 2003. With this historically important document, EU decided that the use of force is necessary to enable stability and welfare to the territory and put forward a foreign politics frame depended on preventive undertaking.

The abilities of ESDP are still backwards. The aim of training 60.000 military personnel in 60 days could not be met. To tell the truth, a great part of the European soldiers are situated in the missions of EU, NATO and UN in all over the world (Jean-Yves Haine, 2006). We can say that ESDP was 
not able to reach the demanded lvel when considered within the light of Haine's explanation. When we evaluate the effect of ESDP on Turkey - EU relationship, the trump of Turkey in front of EU in relation to NATO.

The contributions of Turkey to the ESDP acts are given below (Armağan, 1995):

- 370 personnel aid to the EUFOR-ALTHEA act starting from its beginning and 23 gendarmerie personnel aid to the Integrated Police Unit. In 2006, it is planned that the military aid wil remain the same but the gender mire aid will increase to 46 by doubling. 6 personals are sent by Security General Directorate and 6 personals by Gendarmerie General Commandership, that is a total of 12 personnel are sent to the EU Police Mission in Bosnia Herzegovina started on January 2003, which was the first civil crisis management operation of ESDP. It was decide that 3 police and 6 gendarmeries to be sent to EUPM - II Mission that started on January 1, 2006.

- One police officer worked between March 31, 2005 and September 13, 2005 on EUPOL Kinshasa Police Mission and the other officer started on December 16, 2005. It was proposed that a police officer to be sent to EUPOL COPPS mission founded as a support to the Palestinian police in Ramallah and an answer is being waited from EU. Our country is also supporting EU Combat Groups. It is decided that the Combat Group founded by Turkey, Italy and Romania will have a total acting ability in 2009 and that it will be declared to EU in 2010. Turkey is supporting ESDP. EU needs Turkish Armed Forces Foundation, which has a low level of combat experience and peace operation experience. When EU starts to develop defence politics, this need will increase. Turkey ranks as the first country which provides support to ESDP with civil and military supports although it is not a member of EU.

The geo-politic influence area of Germany is felt in general in this period. The new concept of EU that is being developed within the EU's Common Security and Defence Politics includes the aims of changing sovereignty structures in Eastern and southern territories outside NATO's functions. In other words, the geo-politic influence of EU and Turkey is being intersected and conflicting with each other in Albania, Macedonia, Kosovo, Bosnia, Bulgaria, Western Thrace, Ukraine and Georgia. 


\subsection{Turkey's Status on the Balance of European Security and Defence Policies}

There have been some approaches in analysis of the relationship between European Union and Turkey, describing European Union-Turkey relationship as an unrequited love along with those containing the belief that the process may end up in a negative way. Within the process, which has been excessively dramatized, mutual declarations of bona fides and final opinions have continued their existence. Lessons from historical experiences gains more different meanings if the subject is Turkey-EU relationship (Kongar, 2001). However, innovations in today's global market require elimination of such experience and rearrangement of relationship according to mutual benefits. On this point, the principle of mutual dependency in the new international system has accelerated bilateral relations. Recent progress in Turkey-Europe relationship basing on a long historical background, and their influences on the security model planned setting forth in Europe are of high importance. Turkey's EU candidate status for over 40 years, participation into the same military alliance in Cold War period and close interest of EU in the military encirclement around Turkey are evident in the way that they refer to the position of mutual relationship from the past till today. Non-existence of a divided opinion on the security point to date except the Cyprus issue manifests the significance of the situation

Turkey has been in close relationship with European countries in organizations such as NATO, OSCE and WEU, to which it has been a member. Turkey has also closely monitored the security policies implemented after the end of cold war in Europe, and preferred to participate into these new organizations. Considering the NATO experience with Turkey and the close relations in OSCE, EU countries have not given a negative response to the requests of Turkey for inclusion in this new security organization, even at the Washington summit of 1999 (Ganser, 2005). However, during the summits in Köln and Helsinki towards the end of 1999, EU countries were observed to have preferred a change of policy on this issue. While it was confirmed in Washington summit that a military unit to be established so as to benefit from opportunities and capabilities of NATO may participate into operations of non-member countries of NATO at high level, this criterion was not taken into consideration in Köln summit. In other words, it is aimed that only the EU member countries could access 
these opportunities and capabilities, which are planned to be used within the frame of European Security and Defense Policies (ESDP), and it was revealed that the aim was to evaluate the non-EU member countries which are members to NATO in a different category. The countries, which are members to NATO but not to EU, are: Turkey, Norway, Iceland, Hungary, Czech Republic, and Poland (Özdal, 2005: 314-315). By-pass of the resolutions in Köln summit which were previously passed in Washington summit led to objection by Turkey, basing legally on the resolutions in 1999 NATO summit. Within this context, Turkey's objection seems to contain the purpose of inclusion in decision mechanisms of ESDP and maintaining its advantageous position which it obtained earlier with WEU. Having an active position in ESDI with the advantage provided through NATO membership, Turkey's inability to be involved with ESDP is a major loss in its own terms. Nevertheless, no satisfying decisions were taken in favor of Turkey in the following summits in Helsinki, Feira and Nice, and the basic problem creating tension in mutual relationships could not be eliminated, either. After the damage of this status on its own security benefits, Turkey had to assign the Balkans, which it had regarded within its domain, to the control of Europe.

The counter-declaration of Turkey against this unfair situation that it may interpose its veto on utilization of opportunities and capabilities of NATO within the scope of ESDP triggered the attempts for a consensus (Muitercimler, 2000). Upon the action for solution of the current dispute, a text called "Ankara Agreement" was entered into force between Turkey, England and USA in December 2001. With the following Nice Implementation Documentation undersigned on 24 October 2002, the course of both NATO-EU and Turkey-EU relationship were identified. According to the said documentation, Turkey will directly participate in operations to be executed under the leadership of EU if the opportunities and capabilities of NATO are to be used in these operations. However, as for operations in which opportunities and capabilities of NATO are not to be used, Turkey may participate in this institution by providing that the invitation of the European Council (Hürsoy, 2005:38).

On the other hand, it is a known fact that the aim of EU in an operation in which it will use its own opportunities and capabilities is to intervene in trouble areas with an integrated policy, without dependency on USA and, 
therefore, NATO (Serdar, 2003). The trouble areas, which EU plans to intervene within the frame of ESDP, are Middle East, the Caucasus, the Balkans and Middle Asia. Intervention in such areas without Turkey in decision mechanisms of EU may bring along intricate problems. It is highly possible for EU to experience failure in crisis actions if it does not benefit from historical experiences of Turkey, which stands as the protector of the area. In addition, it is an indisputable fact for all the countries of the said area that Turkish Army has a well trained professional personnel equipped with military hardware of the latest technology (Napoleoni, 2004).

Bypassing this reality will eliminate the success of ESDP. Nevertheless, Turkey is to reinforce its advantageous status about the issue of Turkish Armed Forces (TSK) with diplomatic achievements and defence its own national benefits, casting aside "wait and see" policies. Turkish Army is a deterrent force in its own domain in terms of both human and armed forces. Therefore, it may theoretically be seem possible for European Union to be effective in the above mentioned trouble areas, yet it is not possible in practice (Huntington, 1995). As European Union has participated in peacekeeping duties yet remained away from being a peace-making effect so far, it is evident in the aspect that it manifests efficiency/inefficiency of ESDP. In this regard, it is a necessity for Turkey to take correct strategic steps in negotiation process.

\section{Turkish -American Relations}

During the Cold War period, Turkey was one of the most important branches of West alliance. USA, West Europe and Turkey, as the members of NATO, had become allied on an opposing point of view against the expansion of Soviet Union. The wind of alliance of the term made itself visible not only regarding the issue of opposition but also about the factors they were going to protect. The importance attached to Soviet Union has an obvious power to give direction to the relations. However, this atmosphere of alliance slowly lost its effect after the period of Cold War.

Washington government has restarted the process of providing a suitable systemic structuring by releasing the obstacles before the hegemony it had been constructing in the last ten years after the $11^{\text {th }}$ September. Obligation to make new arrangements in Europe, Asia, Caspian Region and Middle East also makes it inevitable to incur new costs. Charging this cost again in the neighbour countries as in the past will make the stability temporary 
(Bauman, 1999). It is obvious that an international system founded on distrust will present new opportunities to some central countries, however it is also observed that it also bears some risks that may endanger the security of these countries in the long-term period. Initiations have been taken to build a new international system, however it is not certain yet whether the way to a Machiavellian method in which anything goes in the race to have a share or a more fair structure via international institutionalisation will be adopted. If fair arrangements are not made by reviewing the policies of the past, the issue of ensuring the stability in the international system which is being tried but somehow not succeeded will still be an issue to be spoken about.

Developments in Northern Iraq and the existence of PKK in the region have been going on as an important zone of problem in Turkish-American relations. Turkey demands more effective precautions including military interventions from USA against the existence of PKK in Northern Iraq, which is being a threat against Turkey. It is being observed that USA has been employing non-military methods against PKK such as destroying the financial sources and attaching the criminals and putting them in prison. Barzani, who doesn't hide his desire to establish an independent Kurdish State, comes against a military action against PKK, which is another armed Kurdish group, in the Kurdish region, which is being established under the protection of USA. Increasing anxiety of Turkey against the activities of PKK has lead to frequent discussion of the issue in the relations with USA and a search for "increasing the measures". At this very point some has started to talk about the fact that USA will not start a total military action against the activities of PKK, however it will be possible to make operations on smaller scales.

In the report of Washington government called "National Security Strategy in the New Century" issued in October 1998 strategic targets were put under three titles (Napoleoni, 2004). These are; enhancing the security and economic welfare of USA and ensuring the development of democracy in the international arena. It is being thought that ensuring these targets will serve to the interests of USA classified as vital, important and humane. And the threats against USA interests were classified as states that may be threats to the vital interests of US, international threats such as terrorism, threats that may occur as a result of widening of technologies enabling the 
manufacturing of nuclear and biological arms, threats that may come into existence as a result of foreign intelligence operations in diplomatictechnological-military-commercial fields and threats that may occur as a result of instability to be created by countries which have been experiencing civil war.

As a result of conflict of search of USA for an understanding of "security" in different regions of the world in line with the vital interests of USA with the interests of some central countries, the problems of insecurity in the restructuring of the system have occurred, besides it is being observed that neighboring countries have been the parties exposed to harm by staying in between the rivalry. As a result of Washington's effort to become efficient in all crisis zones of the world the importance of its relations with its allies has also increased. As a result of official message crisis between Turkey and USA, the tension between Turkey and USA has also increased (Mütercimler, 2000).

Even if the scope of Big Middle East Project has not been clearly specified yet, USA needs the support of Turkey in order to ensure the stability in Middle East. Participating in European Union does not necessarily mean breaking off relations with USA; moreover there are many points that can both be benefited by Europe and USA from Turkey regarding the global security. In case Turkey, which has been contributing to world peace by the experiences it has within NATO, can employ the military means it owns in an active political manoeuvre area as an efficient trump, its efficiency will improve.

\section{Conclusion}

The theoretical and practical changes occurred in the international system as a result of the dissolution of the two-polar world, the security project developed within the frame of the European Security and Defence Policy (ESPD) was compulsory. The sensitivity and decisiveness of the members of the EU, especially France can be observed on the matter during the period from WEU to ESPD. As a result of the Treaty of Amsterdam, the WEU was integrated into the ESPD and this is the reflection of this decisiveness. The importance of the expansion on the development of the common security, defence and foreign affairs system cannot be ignored. Therefore, after the Cold War, in terms of the functioning of the security policies, 1997 Treaty of Amsterdam, Köln, Helsinki, Feira, Nice and 2001 
Laekan Summits are the turning points. When the processes of the EU on ESPD area are considered, the seriousness of the project can be clearly seen. Despite all these developments, it cannot be said that there is not any problem. Since England and Denmark, who are called as opposers, are away from the common foreign affairs and security policies. The recent Iraqi War indicated once more that EU has to cover a distance on its way. European Security and Defence Policy, in terms of real-politics, cannot be an alternative with its capacity and sufficiency to NATO in the short or middleterm. There is no doubt that the USA cannot be considered to let such a competition. Although the NATO dominance will continue in the short or middle-term on Europe, EU cannot be expected to be stable on development of common security and foreign affairs policy. The global changes following the $11^{\text {th }}$ September make Europe obligatory to try on the matter.

On the other hand, power and interest relations that are the determiners of the current international relations, will bring different security pacts according to the future conditions that will probably change. The close relations of the EU members apart from the opponents of the USA, France and Germany with USA indicate that there will be cooperation and interdependence between EU and the USA. The recently exclusion of Turkey from the ESDP where Turkey was in from the very beginning, will may cause the infirmity of the EU on ESDP. EU should consider the role that Turkey may play on the interventions of Europe who will be reluctant to use NATO on the crisis regions according to expected situations and should prepare a new action plan. Therefore, the EU cannot dare to exclude Turkey completely, this can be seen on Treaty of Ankara and Nice documents. The duty of Turkish State, on the other hand, is to get rid of the formations that can be damage the security interest. On that point, Turkey must be more active on foreign affairs to disappear its image on the eyes of the peoples of the Republic; "diplomacy goes on, Turk hold on".

The USA has supported Turkey for ESDP, like its support for the EU, and it tried to be an arbitrator between Turkey and the EU. On December 2001, there was conciliation among the USA, England and Turkey in accordance with the reservations of Turkey, but Greece was vetoed, so the solution could not be provided. In Copenhagen, the veto of Turkey enabled to take precautions to end the veto, however, Turkey could not find a satisfactory conclusion. Today, while the one-pole world system is ending, 
the struggles of the global actors with each other are going on. The distinction between the USA and the EU, who have acted together historically, become more obvious. Especially, the discussions on the legal foundation of the Iraqi intervention and the common action strategy of France and Germany increased the tension between the USA and the EU. Fistly, the operation was called as Iraqi intervention and then called as Iraqi occupation and European countries decided to call back their troops from Iraq. During all these discussions, since Turkey did not accept military permission and did not support the USA, there was a crisis between permanent aligns and in relations between the USA and Turkey was plugged. Besides, the close contact of the EU with Turkey and the steps of Turkey towards democratisation cause a warm atmosphere. The disputes on Cyprus have a potential to plug the relations in the future, since there are negative declarations about Turkey and interior dynamics of the country are harmonized with the crisis, still Turkey is an important country for the EU in terms of geo-politics, geo-cultural, geo-strategic and the EU needs Turkey as ally to increase its effectiveness on world.

Turkey, who is between the USA and the EU security policies, has to choose one of them to guarantee its own security on war against terror, international smuggling, and military policies by unthreatening the other party with its flexibility and politeness. In my opinion, in case if Turkey chooses the USA, it will be its margin patrol in the Middle East as it is said in classical discussions. Therefore, the Extended Middle Eastern and African Project defines Turkey as light Islamic country and presents Turkey as a model for the Middle East countries. However, it is not clear how much the countries will accept this model and how much Turkey will fit into such a role, these points are very controversial. On the other hand, Turkey in the security policies of the EU which is a civilization project, will reach the horizon that it has seen since it was established and save itself from being perceived as an ordinary country apart from its military power and become civilized, modern, pluralistic country.

The tension between the USA and the EU will increase in different areas. The USA guarantee not to intervene on interior security matters that have a high cost and low turnover, to Europe. However, the USA seem not to follow the same approach on matters that are Europe-centric but related with the world security and does not accept any alternative to NATO that is in control of the USA. Under these conditions and conjuncture, either the 
strategic relations of Turkey with the USA especially on security or the perspective on EU membership which has a past for more than 40 years and very few to the result, Turkey is at the centre of these discussions. The security of Turkey depends on its understanding and choice that it is at the parting of the ways and both the USA and the EU may become a threat for it.

The European Union knows that it cannot have an army without the support of the United States of America and follows a very careful strategy on NATO. In the near future, the dependency of the EU countries to NATO will go on since they even do not plan to increase their expenditures on defence. Turkey should be able to use the tension between the USA and the EU by taking advantage and be a balancing power on its geography by increasing its influence. Turkey should develop its relations with EU to take part in the ESDP that is the major security institution of the EU and needs to produce reliability during these relations. In this respect Turkey, has to develop a relation based on mutual trust according to its place in the European Atlantic Institutions. The trust is the basic to act together on security policies.

\section{References:}

Altuğ, Yılmaz (1995). Terörün Anatomisi. İstanbul: Altın Kitaplar.

Arı, Tayyar (2002). Uluslararası Illişkiler Teorileri. İstanbul: Alfa.

Armağan, Mustafa (1995). Gelenek ve Modernlik Arasında. İstanbul: İnsan Yayınları.

Bauman, Zygmunt (1999). Küreselleşme. İstanbul: Ayrıntı.

Born, Hans (2005). Güvenlik Sektörünün Parlamenter Gözetimi. İstanbul: Tesev.

Brzezinski, Zbigniew (1997). Büyük Satranç Tahtast. İstanbul: İnkılap.

Chomsky, Noam (1993).Yeni Dünya Düzeni (Çev: Kadir Çağlayan). İstanbul: Ağaç Yayınlan.

Çalış, Şaban (2001). Türkiye'nin Dış Politika Gündemi. Ankara: Liberte. 
Çayhan, E. - Ateşoğlu, N. (1996). Avrupa'da Yeni Güvenlik Arayışları $N A T O, A B$, Türkiye. İstanbul: Afa.

Çomak, Hasret (2005). Avrupa'da Yeni Güvenlik Anlaylşları ve Türkiye. İstanbul: IQ Kültür.

Davutoğlu, Ahmet (2001). Stratejik Derinlik. İstanbul: Küre Yayınları.

Dedeoğlu, Beril (2003). Uluslararası Güvenlik ve Strateji. İstanbul: Derin Yayınlan.

Erdoğdu, Hikmet (2004).Avrupa'nin Geleceğinde Türkiye'nin Önemi ve NATO İtifakt. İstanbul: IQ.

Fuller, Graham (1996). Kuşatılanlar: İslam ve Batı'nın Jeopolitiği. İstanbul: Sabah.

Ganser, Daniele (2005). NATO'nun Gizli Orduları. İstanbul: Güncel Kitabevi.

Gnesotto, Nicole (2005). AB Güvenlik ve Savunma Politikası. İstanbul: Tasam.

Gürkaynak, Muharrem (2004). Avrupa'da Savunma ve Güvenlik. İstanbul: Asil Yayınları.

Huntington, Samuel (1995). Medeniyetler Çatı̧̧ması. İstanbul: Vadi.

İçli, Tülin Günşen (2003). Uluslararası Güvenlik ve İ̧̧ Güvenlik. Ankara: Nobel.

İnaç, Hüsamettin (2005). AB'ye Entegrasyon Sürecinde Türkiye'nin Kimlik Problemleri. Ankara: Adres Yayınları.

İnaç, Hüsamettin (2006). Faşizmin ve Sosyalizmin Sosyo-politik Kökenleri. Bursa: Ekin Yayınlanı.

Kona, Gamze Güngörmüş (2005). Uluslararası Çatı̧̧ma Alanları ve Türkiye'nin Güvenliği. İstanbul: IQ Yayınları.

Kongar, Emre (2001). 21. Yüzyılda Türkiye. İstanbul: Remzi Kitabevi.

Kongar, Emre (2002). Küresel Terör ve Türkiye. İstanbul: Remzi Kitabevi.

Moussis, Nicholas (2004). Avrupa Birliği Politikalarına Giriş Rehberi. İstanbul: Mega. 
Mütercimler, Erol (2000). 21. Yüzyll ve Türkiye. İstanbul: Güncel Kitabevi.

Napoleoni, Loretta (2004). Modern Cihat. İstanbul: Bulut Yayınları.

Norton, Augustus Richard (2000). Ortadoğu Politikalarl ve Güvenlik Yeni Yönelimler. İstanbul: Büke Yayınları.

Oran, Baskın (2002). Türk Dış Politikası, Cilt 1:1919-1980. İstanbul: İletişim.

Özcan, Gencer (2000). En Uzun On Yll. İstanbul: Büke.

Özey, Ramazan (1997). Jeopolitik ve Jeostratejik Açıdan Türkiye. Ankara: Marifet.

Öztürk, Osman Metin (1997). Anayasal Düzeyde Savunma ve Güvenlik Yapılanmasl. Ankara: Vadi Yayınları.

Şimșek, Halil (2002). Türkiye'nin Ulusal Güvenlik Stratejisi. İstanbul: IQ Kültürr.

Touraine, Alain (2000). Eşitliklerimiz ve Farkllliklarımızla Birlikte Yaşayabilecek miyiz?İstanbul: Yapı Kredi Yayınları.

Ülger, İrfan Kaya (2002). Avrupa Birliğinde Siyasal Bütünleşme. Ankara: Gündoğan.

Ülger, İIfan Kaya (2003). Avrupa Birliği El Kitabı. Ankara: Seçkin. 